\title{
Antibacterial and photocatalytic performance of Silver orthophosphate/Hydroxyapatite composite
}

\author{
Ahmed Elyacoubi ${ }^{1, *}$, Amine Rkhaila ${ }^{2}$, Brahim sallek ${ }^{3}$ and Brahim Chafik El idrissi ${ }^{1}$ \\ ${ }^{1}$ Chemical Team Materials Surfaces Interfaces, Laboratory Materials and Energetics, Fac of Sciences, Ibn Tofail \\ University, kenitra, B.P: 133, Kénitra, Morocco \\ ${ }^{2}$ Laboratory of nutrition, health and environment; Applied microbiology team. Ibn Tofail University. Morocco \\ ${ }^{3}$ Agroressources and process engineering laboratory, Ibn Tofail University, Kénitra, Morocco
}

\begin{abstract}
The present work reports the synthesis of pure hydroxyapatite and $\mathrm{HAp}$ supported $\mathrm{Ag}_{3} \mathrm{PO}_{4}$ $\left(\mathrm{Ag}_{3} \mathrm{PO}_{4} / \mathrm{HAp}\right.$ composites) with varying amounts of silver ions Ag+ with a facile in-situ ion exchange method. XRD results of $\mathrm{Ag}_{3} \mathrm{PO}_{4} / \mathrm{HAp}$ composite reveal the peaks characteristic of pure HAp with additional peaks of silver ions which suggest the deposit of silver particles on the support surface (HAp). The nano-composites $\mathrm{Ag}_{3} \mathrm{PO}_{4} / \mathrm{HAp}$ samples show good adsorption and improved photocatalytic activities in methylene blue MB degradation (more than 70\%). Antibacterial study of $\mathrm{Ag}_{3} \mathrm{PO}_{4} / \mathrm{HAp}$ nano-composites showed that the $\mathrm{HAp}$ dried at $90^{\circ} \mathrm{C}$ possesses some antibacterial activity against Escherichia coli and Staphylococcus aureus bacteria. Also, compared to HAp sample, deposition of $\mathrm{Ag}_{3} \mathrm{PO}_{4}$ nanoparticles on HAp surface improves the antibacterial performance of the composites.
\end{abstract}

Keywords: Hydroxyapatite; silver orthophosphate; Gram-positive and Gram-negative bacteria; photodegradation.

\section{Introduction}

Nowadays, the textile industries and photographic industries reject vast quantities of polluted wastewater. The purification of water from chemical products and microbial contaminations has become a great environmental challenge. Semiconductor-based photocatalysis seems to be a promising and efficient material to decompose pollutants substances using solar light. Among many photocatalysts, titanium oxide $\left(\mathrm{TiO}_{2}\right)$ is widely used thanks to its high photocatalytic activity and chemical stability ${ }^{1}$. Unfortunately, $\mathrm{TiO}_{2}$ shows good photocatalytic activity only under ultraviolet (UV) $(<387 \mathrm{~nm})^{2}$, which limits its use as a photocatalytic material. Therefore, it is necessary to look for other possible alternative photocatalysts to $\mathrm{TiO}_{2} \cdot \mathrm{Ag}_{3} \mathrm{PO}_{4}$ was recently found as an alternative photocatalyst material for solar photocatalysis, which can oxidize water and decompose organic dye with excellent photo-oxidation activity ${ }^{3}$. The photodegradation performance of $\mathrm{Ag}_{3} \mathrm{PO}_{4}$ was found to be higher than that of other classical photocatalysts such as $\mathrm{N}-\mathrm{TiO}_{2}$ and $\mathrm{BiVO}_{4}{ }^{4,5}$. Umezawa and co-workers studied the origin of high photocatalytic performance using the density functional theory based on the first principles calculations indicating that $\mathrm{Ag}_{3} \mathrm{PO}_{4}$ had a large dispersion of conduction band facilitating the separation of electron/hole pairs $\left(\mathrm{e}-/ \mathrm{h}^{+}\right)^{6}$.

However, Silver phosphate can be reduced to metallic silver $\mathrm{Ag}^{0}$ during the photodegradation reaction. Also, the photoinduced electron (e-) cannot react with $\mathrm{O}_{2}$ to form $\mathrm{O}_{2} \cdot{ }^{-}$because the conduction band $\mathrm{CB}$ position is more positive than that red/ox potential of $\mathrm{O}_{2} / \mathrm{O}_{2} .^{-}\left(\mathrm{E}^{\circ}=-0.33 \mathrm{~V}\right){ }^{7}$. Therefore, the photoinduced electrons cannot be combined with $\mathrm{O}_{2}$ to form reduction products, which is necessary for the photodegradation process. To enhance the performance of photoinduced electrons for $\mathrm{Ag}_{3} \mathrm{PO}_{4}$ material various methods have been adopted by coupling and constructing a heterogeneous junction between $\mathrm{Ag}_{3} \mathrm{PO}_{4}$ and another semiconductor supports such as $\mathrm{Ag}_{3} \mathrm{PO}_{4} / \mathrm{TiO}_{2}{ }^{8}, \mathrm{Ag}_{3} \mathrm{PO}_{4} / \mathrm{Graphene} \mathrm{oxide}^{9}$ and $\mathrm{Ag}_{3} \mathrm{PO}_{4} / \mathrm{SnO}_{2}{ }^{10}$. Due to its properties such as biocompatibility, bioactivity and biodegradability, Hydroxyapatite $\mathrm{HAp}$, with chemical formula $\mathrm{Ca}_{10}$ $\left(\mathrm{PO}_{4}\right)_{6}(\mathrm{OH})_{2}$, is a potential candidate to be used as catalyst support and as a support for inorganic antibacterial agents. HAp supported $\mathrm{Ag}_{3} \mathrm{PO}_{4}$ proves to be a promising material for visible light activated photocatalyst. 
On the other hand, HAp particles could be contaminated by bacteria during the synthesis or implantation stage. It has been noticed that the HAp does not present any antibacterial activity which limits its use as implant ${ }^{11}$. However, Tin-Oo et al. ${ }^{12}$ reported that HAp possesses some antibacterial activity with the broth dilution technique. Hence, the improvement of HAp antibacterial activity has become essential and necessary to ensure the implantation of the HAp biomaterial without any bacterial infections. In this regard, one of the ways to improve the antibacterial activity of HAp is using metal ions to minimize the risk of bacterial contaminations and therefore prevent the growth of pathogens on the implant surface. Various metal ions such as $\mathrm{Ag}^{+}, \mathrm{Zn}^{2+}$ or $\mathrm{Cu}^{2+}$ can be used in the coating of the implant to eliminate the bacterial adhesion and growth 13,14 . One of these ions, which present an excellent antibacterial activity, is $\mathrm{Ag}^{+}$thanks to its substantial toxicity property towards a broad range of pathogens ${ }^{15} . \mathrm{Ag}^{+}$ions are also very well known for their antibacterial properties and non-toxic characteristics to human cells at low quantities. The cytotoxicity of $\mathrm{Ag}^{+}$might be due to size, the shape of particles and also to their accumulation inside human cells, leading to their dysfunctions ${ }^{16}$. So, coupling the $\mathrm{Ag}_{3} \mathrm{PO}_{4}$ and HAp proves to be useful and beneficial to enhance the antibacterial activity of implants if they are used in feeble concentrations.

The present work aims to synthesize the nanocomposites of HAp supported $\mathrm{Ag}_{3} \mathrm{PO}_{4}$ with varying amounts through a facile in-situ ion exchange method as well as silicon-substituted HAp (SixHAp) by the wet chemical precipitation method. The synthesized nano-composites were analysed by XRD technique. In order to understand the effect of the support on the $\mathrm{Ag}_{3} \mathrm{PO}_{4}$ photocatalysis, the photodegradation of $\mathrm{MB}$ under visible light irradiation was investigated. The effect of $\mathrm{Ag}_{3} \mathrm{PO}_{4}$ deposited on HAp surface on the antibacterial activity of HAp was studied through disk diffusion method by measuring the zone inhibition for each sample against Escherichia coli (E. coli) and Staphylococcus aureus (S. aureus).

\section{Materials and methods}

\section{Synthesis of samples}

Pure Hydroxyapatite (HAp), as a support, was synthesized via conventional aqueous precipitation method as it was briefly dealt in our previous paper ${ }^{17}$. Briefly, $0.925 \mathrm{~g}$ of calcium hydroxide $\mathrm{Ca}(\mathrm{OH})_{2}$ was dissolved in $25 \mathrm{ml}$ of deionized water DI and stirring for $15 \mathrm{~min}$ at room temperature. Concurrently, $0.720 \mathrm{~g}$ of phosphoric acid $\left(\mathrm{H}_{3} \mathrm{PO}_{4}\right)$ was dissolved in $25 \mathrm{ml}$ of DI water and stirring for $15 \mathrm{~min}$ and added drop by drop, under stirring, to the already prepared solution of $\mathrm{Ca}(\mathrm{OH})_{2}$. The $\mathrm{pH}$ of the slurry remained higher than 10 (no ammonia was added). The resultant mixture was stirred for $2 \mathrm{~h}$ and then matured over $48 \mathrm{~h}$ at ambient temperature. The as-prepared precipitate was filtered and dried at $90^{\circ} \mathrm{C}$ for $24 \mathrm{~h}$.

The $\mathrm{Ag}_{3} \mathrm{PO}_{4}$ nanoparticles were prepared by the liquid-solid method, and $0.408 \mathrm{~g}$ of silver nitrate (Riedel-de Haën, 98.5-100\%) directly added under stirring to $20 \mathrm{ml}$ of an already prepared $\left(\mathrm{NH}_{4}\right)_{2} \mathrm{HPO}_{4}$ (LOBA CHEMIE) solution $(5.4 \mathrm{~g} / \mathrm{L})$. After $2 \mathrm{~h}$ of agitation, the resulting paste was filtered and dried at $80^{\circ} \mathrm{C}$ for $12 \mathrm{~h}$. On the other hand, to synthesize $\mathrm{Ag}_{3} \mathrm{PO}_{4} / \mathrm{HAp}$ nano-composites, $0.5 \mathrm{~g}$ of the biomaterial supports (HAp) was added to $20 \mathrm{ml}$ of DI water and aged for $10 \mathrm{~min}$. Then, $15 \mathrm{ml}$ of nitrate silver precursor, containing the desired quantity of $\mathrm{AgNO}_{3}$ $(0.05,0.1$ and $0.15 \mathrm{~g})$, was mixed with HAp precursor and kept under stirring for $4 \mathrm{~h}$ at room temperature and matured over $12 \mathrm{~h}$. The yellow product suspensions were removed by filtration, and the remaining particles were dried at $80^{\circ} \mathrm{C}$ for $12 \mathrm{~h}$ to remove the residual water. For reference, the samples were labelled as $\mathrm{Ag}_{3} \mathrm{PO}_{4} / \mathrm{HAp}-1$ with $5,8 \%$ (weight percentage) of $\mathrm{Ag}, \mathrm{Ag}_{3} \mathrm{PO}_{4} / \mathrm{HAp}-2$ (10,6 wt. $\%$ of $\mathrm{Ag}$ ) and $\mathrm{Ag}_{3} \mathrm{PO}_{4} / \mathrm{HAp}-3$ (14,6 wt. $\%$ of $\mathrm{Ag}$ ) and the amount of $\mathrm{AgNO}_{3}$ added is $0.05 \mathrm{~g} 0.1 \mathrm{~g}$ and $0.15 \mathrm{~g}$ respectively.

\section{Powders characterization}

The identification of crystallites phases of all samples was investigated by Philips X'Pert PRO $\mathrm{X}$-ray diffractometer (XRD) using $\mathrm{CuK} \alpha$ radiation $(\lambda=1.5406 \AA)$ at $40 \mathrm{kV}$ and $30 \mathrm{~mA}$. The XRD patterns were collected in the $2 \theta$ range of $10-60^{\circ}$ with a step of $0.02^{\circ}$. The morphological characteristics of as-synthesized nanoparticles were carried out by scanning electron microscopy (SEM, Hitachi, S-3400N).

\section{Photocatalytic measurements}

The as-prepared photocatalysts were evaluated through the photodegradation of the MB organic pollutant in aqueous solution under visible light irradiation (36W LED lamp). $50 \mathrm{mg}$ of each photocatalyst was dispersed into $50 \mathrm{ml} \mathrm{MB}$ solution dye $(20 \mathrm{mg} / \mathrm{l})$, and then the result suspensions were stirred in the dark for 30min to establish adsorptiondesorption equilibrium between $\mathrm{MB}$ and photocatalysts. After irradiation time, the MB aqueous solution was sampled and centrifuged to eliminate the photocatalysts. The remaining concentration of MB was measured using a UV-vis spectrophotometer (Jenway, Serial: 67XX) and the decolorization efficiency (\%) was calculated by the following equation (1):

Decolorization $(\%)=\left(\mathrm{C} / \mathrm{C}_{0}\right) \times 100 \%=\left(\mathrm{A} / \mathrm{A}_{0}\right) \times 100 \%$

Where $\mathrm{C}_{0}$ and $\mathrm{A}_{0}$ were the initial concentration and initial absorbance of MB respectively, while $\mathrm{C}$ and $\mathrm{A}$ were the concentration and absorbance after the irradiation of visible light respectively. 
In an attempt to understand the effect of the silver percentage on the antibacterial activity compared to HAp as a control, the antibacterial properties were carried out against two kinds of bacteria strain: Staphylococcus sharp and intense peaks indicate the high purity (S. aureus) and Escherichia coli (E. coli) as Gram-positive and Gram-negative strains, respectively. The used pathogens were isolated from the nutrition, health and environment laboratory; by the microbiology team, at Ibn Tofail University in Morocco. The test evaluation is performed by the disk diffusion method. The disks of filter paper (Woltman $\mathrm{n}^{\circ} 1$ ); with a diameter of $5 \mathrm{~mm}$; emerged for $24 \mathrm{~h}$ in the solutions containing the samples already sterilized by tyndallization (at $60^{\circ} \mathrm{C}$ over $30 \mathrm{~min}$ then $5-10^{\circ} \mathrm{C}$ over
$30 \mathrm{~min})$. The diffusion technique was performed using the Müller-Hinton Agar (MHA). The zone plates were carried out by filling the used agar into Petri dishes, then $1 \mathrm{~cm}^{3}$ of the $\left.10^{8}(\mathrm{cfu} \mathrm{cm})^{-3}\right)$ suspension of each tested species was poured and spread over the MHA medium previously prepared simple (the bacterial culture was 24 hours old). The as-prepared disks (already emerged) were deposited on the medium culture and incubated for $24 \mathrm{~h}$ at $37^{\circ} \mathrm{C}$. The culture of the blank sample investigated in the same conditions, and the same nutrient broth medium is used for all tests. All of the tests were repeated ten times, and their average represented the results. The obtained results were performed by measuring the width of the inhibition zone $(\mathrm{cm})$.
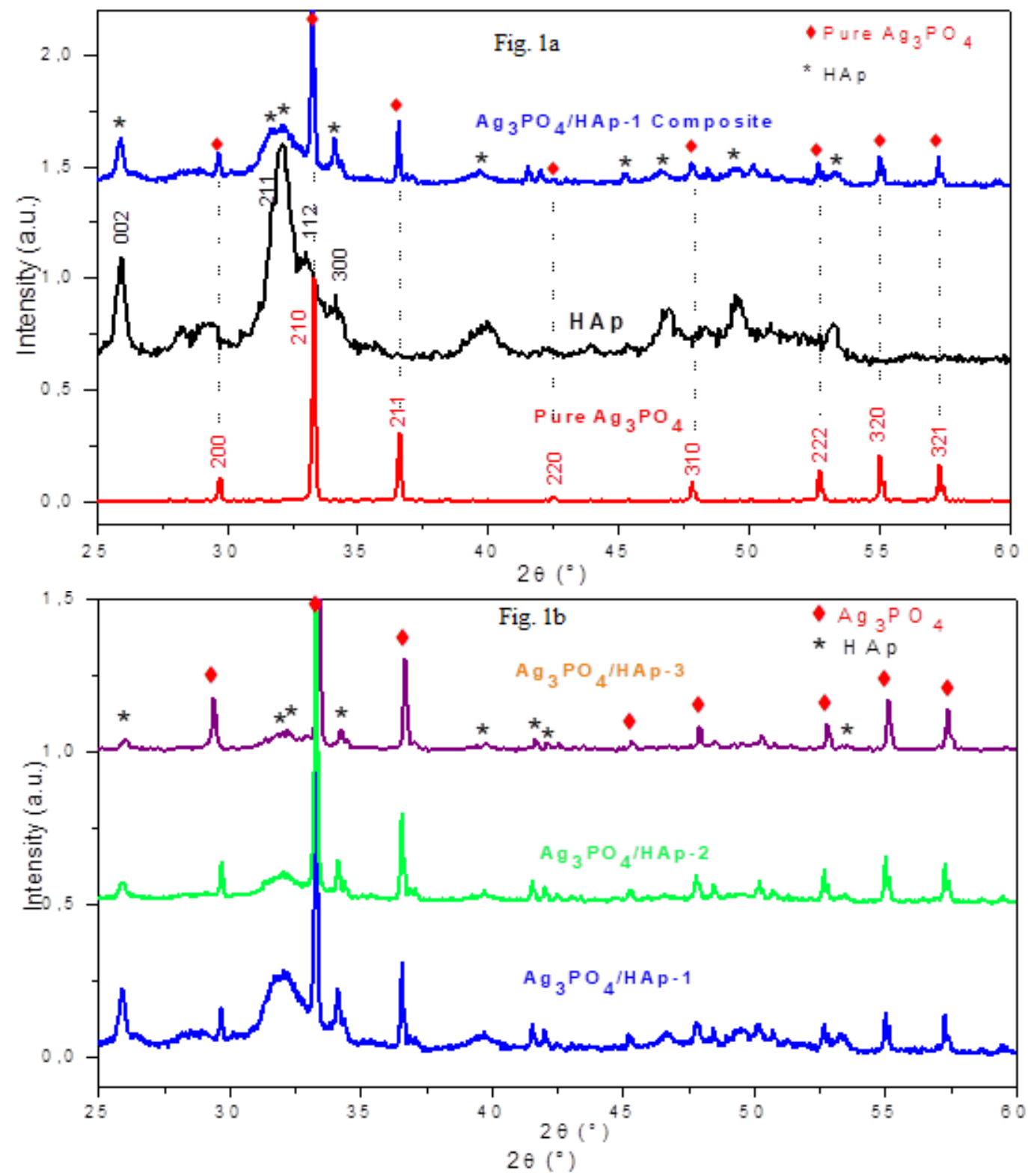

Figure 1. XRD diffraction data of (a) HAp support, pure $\mathrm{Ag}_{3} \mathrm{PO}_{4}, \mathrm{Ag}_{3} \mathrm{PO}_{4} / \mathrm{HAp}-1$ and (b) $\mathrm{Ag}_{3} \mathrm{PO}_{4} / \mathrm{HAp}-1$, $\mathrm{Ag}_{3} \mathrm{PO}_{4} / \mathrm{HAp}-2$ and $\mathrm{Ag}_{3} \mathrm{PO}_{4} / \mathrm{HAp}-3$ composites 


\section{Results and discussion}

\section{Characterization of products}

The phase and the crystallinity of resultant products were investigated by XRD diffraction analysis. Figure 1 shows the XRD patterns of samples. Fig 1-a represents the XRD patterns of pure hydroxyapatite support (HAp) dried at $90^{\circ} \mathrm{C}$, pure $\mathrm{Ag}_{3} \mathrm{PO}_{4}$ and $\mathrm{Ag}_{3} \mathrm{PO}_{4} / \mathrm{HAp}-1$ composite. Fig 1-b shows just the XRD patterns of three composites samples.

All XRD patterns were indexed based on JCPDS card $\mathrm{n}^{\circ}$ 06-505 for $\mathrm{Ag}_{3} \mathrm{PO}_{4}$ and JCPDS Card ${ }^{\circ}$ 9-432 for hydroxyapatite support $\mathrm{Ca}_{10}\left(\mathrm{PO}_{4}\right)_{6}(\mathrm{OH})_{2}$. The important diffraction peaks characteristics of $\mathrm{HA}$ apatite were observed located at $25.89^{\circ}-32.13^{\circ}$ 33.00 and $34.15^{\circ}$ corresponding to (002), (211), (112) and (300) planes, respectively ${ }^{18}$. XRD pattern of pure HAp did not show the presence of any other materials as a secondary phase. The broad peaks of pure HAp reveal the presence of a significant amount of amorphous phase, which is in good accordance with the literature ${ }^{18}$. On the other side, the eight peaks located at $29.77^{\circ}, 33.39^{\circ}, 36.65^{\circ}, 42.50^{\circ}, 47.82^{\circ}$, $52.71^{\circ}, 55.06^{\circ}$ and $57.30^{\circ}$ correspond to the (200), (210), (211), (220), (310), (222), (320) and (321) planes of pure $\mathrm{Ag}_{3} \mathrm{PO}_{4}$ nanoparticles, respectively ${ }^{19}$. Therefore, the sharp and intense peaks indicate the high crystallinity and crystallinity of $\mathrm{Ag}_{3} \mathrm{PO}_{4}$ particles. Lattice parameters and crystallite size of the synthesized $\mathrm{Ag}_{3} \mathrm{PO}_{4}$ particles were calculated using the Full Prof program and Scherrer equation, respectively. The mean estimated crystallite size and lattice parameters were $0.56 \AA$, and $a=6.0139 \AA$, respectively and the structure of $\mathrm{Ag}_{3} \mathrm{PO}_{4}$ microcrystal was determined as a body-centred cubic structure with P-43n space group (JCPDS no 06-0505). Thus the $\mathrm{XRD}$ analysis reveals also that the as-prepared sample of silver nitrate is pure $\mathrm{Ag}_{3} \mathrm{PO}_{4}$ with no detected impurities phases. After impregnation of metallic silver, all composites samples show both the peaks characteristic of $\mathrm{HAp}$ and $\mathrm{Ag}_{3} \mathrm{PO}_{4}$, suggesting the successful deposit of $\mathrm{Ag}_{3} \mathrm{PO}_{4}$ microcrystals on the HAp support surface and confirming their coexistence. As the amount of $\mathrm{AgNO}_{3}$ increase, the characteristic peaks of $\mathrm{Ag}_{3} \mathrm{PO}_{4}$ nano-crystals become increasingly intense.
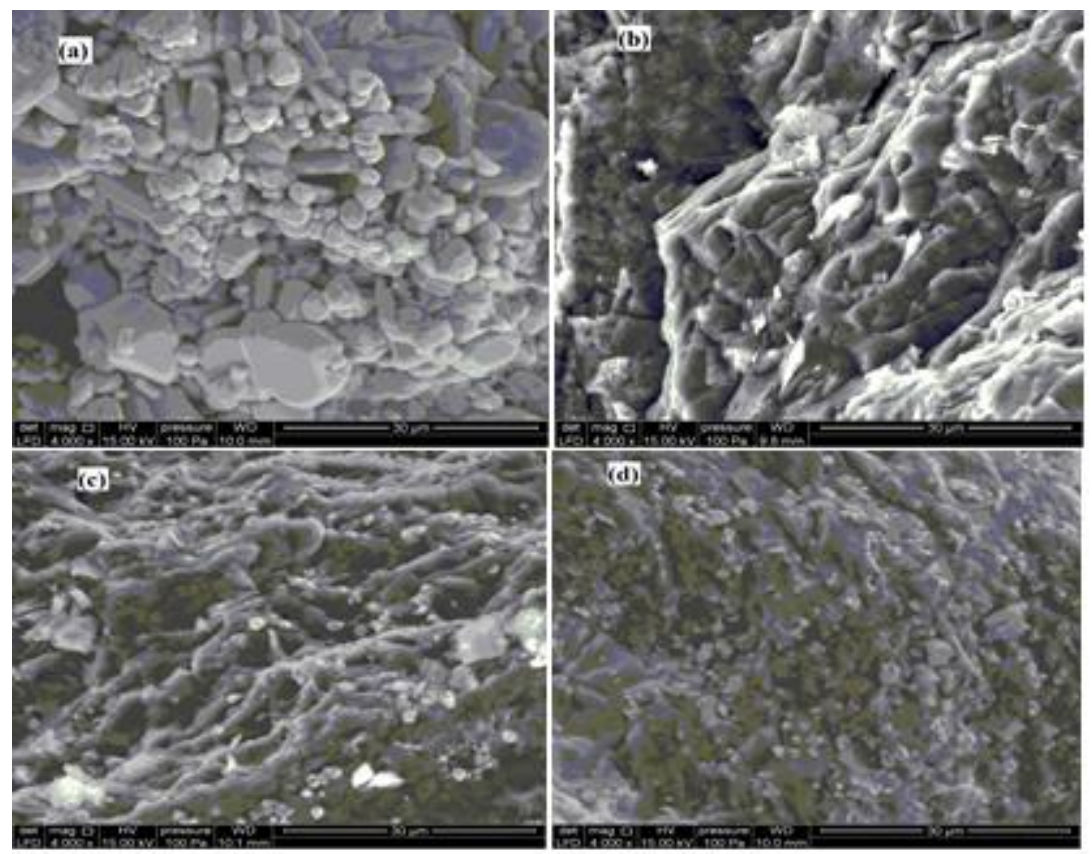

Figure 2. SEM images of (a) $\mathrm{Ag}_{3} \mathrm{PO}_{4}$, (b) $\mathrm{Ag}_{3} \mathrm{PO}_{4} / \mathrm{Hap}-1$, (c) $\mathrm{Ag}_{3} \mathrm{PO}_{4} / \mathrm{HAp}-2$ and (d) $\mathrm{Ag}_{3} \mathrm{PO}_{4} / \mathrm{HAp}-3$

The mean crystallite size ( $\mathrm{L}$ ) of $\mathrm{Ag}_{3} \mathrm{PO}_{4}$ particles was calculated from the XRD data using the Scherrer equation as follow (2):

$$
L=\frac{k \lambda}{\beta \cos \theta}
$$

Where $\mathrm{L}=$ crystallite size, $\mathrm{K}=$ the shape factor equal to $0.9, \lambda=$ wavelength of $\mathrm{Cu} \mathrm{K} \alpha$ radiation equal to $1.5406 \AA, \theta=$ half of the diffraction angle and $\beta=$ full width at half maximum (FWHM), the Scherrer equation is relative to a single peak (210).

The morphologies of as-prepared photocatalysts were characterized by scanning electron microscopy (SEM), and the representative images are shown in Figure 2. It can be seen that the $\mathrm{Ag}_{3} \mathrm{PO}_{4}$ nanoparticles exhibit both a nanorod and irregular polyhedra morphologies with a smooth surface (Fig 2.a). 
The particles size varies than from 1.5 to 9 microns (Fig 2.a). In Fig 2.b-d, we can see the numerous bright particles with a mean particle size of 1-2.5 microns are deposited onto the surface of the support (dark surface) suggesting the deposition of $\mathrm{Ag}_{3} \mathrm{PO}_{4}$ nano-particles on HAp surface. Based on the above SEM images, we can infer that the use of hydroxyapatite support promotes better dispersion and enhances stronger contact with $\mathrm{Ag}_{3} \mathrm{PO}_{4}$. Hence, the anti-agglomeration of $\mathrm{Ag}_{3} \mathrm{PO}_{4}$ nanoparticles can be realized in the samples, which is favourable to the reduction of the particle size of $\mathrm{Ag}_{3} \mathrm{PO}_{4}$ and therefore beneficial to the photocatalytic process.

Figure 3 shows the photocatalytic performance of as-prepared samples to decompose $\mathrm{MB}$ dye after exposing to visible light irradiation. The decolorization of MB dye was measured by absorbance at $664 \mathrm{~nm}$ which is largely taken as a reference to evaluate the decolorization rate of $\mathrm{MB}$ organic dye. Furthermore, the absorbance of MB at $291 \mathrm{~nm}$ could be used to extract information about the degradation stage of the entire dye ${ }^{20}$. For the HAp sample, and according to Figure 3, it can be seen that the MB concentration remains practically unchanged under visible light irradiation in $120 \mathrm{~min}$. In addition, the pure $\mathrm{Ag}_{3} \mathrm{PO}_{4}$ photocatalyst exhibits very good photocatalytic activity under visible irradiation, and $98 \%$ of $\mathrm{MB}$ is decomposed after $60 \mathrm{~min}$ reaction time. The photocatalytic activity of $\mathrm{Ag}_{3} \mathrm{PO}_{4}$ particles depends on the balance between the size and morphology. Xiang et al reported that the $\mathrm{Ag}_{3} \mathrm{PO}_{4}$ nanorods exhibit good photocatalytic activity for dye degradation. Obviously, the good photocatalytic activity can be explained by the nanorod and irregular polyhedra morphology of pure $\mathrm{Ag}_{3} \mathrm{PO}_{4}$ nanoparticles.

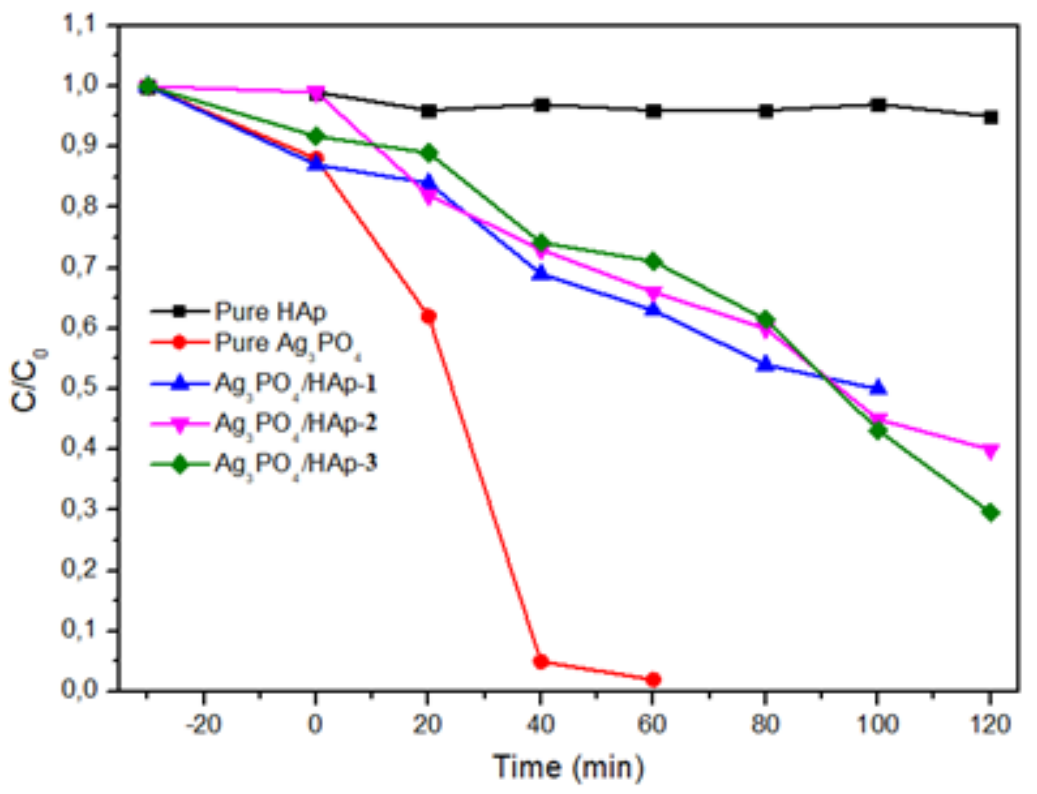

Figure 3. degradation curves for $\mathrm{MB}$ using $\mathrm{HAp}$, Pure $\mathrm{Ag}_{3} \mathrm{PO}_{4}, \mathrm{Ag}_{3} \mathrm{PO}_{4} / \mathrm{HAp}-1, \mathrm{Ag}_{3} \mathrm{PO}_{4} / \mathrm{HAp}-2$ and $\mathrm{Ag}_{3} \mathrm{PO}_{4} / \mathrm{HAp}-3$

Compared with pure $\mathrm{HAp}$, the $\mathrm{Ag}_{3} \mathrm{PO}_{4} / \mathrm{HAp}$ nano-composites show a superior photodegradation rate of $\mathrm{MB}$, which was due to the deposited $\mathrm{Ag}_{3} \mathrm{PO}_{4}{ }^{21}$. It should also be noted that the photocatalytic activity of $\mathrm{Ag}_{3} \mathrm{PO}_{4} / \mathrm{HAp}$ composites increase when the concentration of silver ions increase. Under visible irradiation, $\mathrm{Ag}_{3} \mathrm{PO}_{4} / \mathrm{HAp}-3$ show higher photocatalytic performance compared to other silver hydroxyapatite composites with a decolorization rate of $\mathrm{MB}$ of $70.30 \%$ in $120 \mathrm{~min}$. However, the decolorization rate of $\mathrm{Ag}_{3} \mathrm{PO}_{4} / \mathrm{HAp}-1$ and $\mathrm{Ag}_{3} \mathrm{PO}_{4} / \mathrm{HAp}-2$ are only $50 \%$ and $55 \%$ in $100 \mathrm{~min}$ respectively. We can observe that the decolorization rate of $\mathrm{Ag}_{3} \mathrm{PO}_{4} / \mathrm{HAp}-1$ and $\mathrm{Ag}_{3} \mathrm{PO}_{4} / \mathrm{HAp}-2$ is higher than that of $\mathrm{Ag}_{3} \mathrm{PO}_{4} / \mathrm{HAp}-3$ until $100 \mathrm{~min}$ and vice versa at $120 \mathrm{~min}$. Moreover, a small amount of silver ion could improve the photocatalytic activity due to the slow release of deposited silver ions on the HAp support by photogenerated electrons which leads to the rapid carrier (electrons and holes) separation under visible light irradiation ${ }^{22}$.

\section{Antibacterial assessment}

The antibacterial activities of HAp, pure $\mathrm{Ag}_{3} \mathrm{PO}_{4}$ and $\mathrm{Ag}_{3} \mathrm{PO}_{4} / \mathrm{HAp}$ samples were investigated by measuring the zone inhibition (ZoI) against E. coli and $\mathrm{S}$. aureus strains (Table 1). The antibacterial efficiency of the test is evaluated by measuring the diameter of ZoI around the disk. When the ZoI increases the antibacterial efficiency becomes more critical. Results show that the samples have acted differently on the two bacteria. According to the obtained results, it can be seen that the E. coli strain is less responsive than $\mathrm{S}$. aureus ones to all studied 
compounds (Figure 4). This difference in response might be due to the difference in the cellular wall structure of Gram-positive and Gram-negative strain $^{23,24}$.

Table 1. Average diameter $(\mathrm{cm})$ of zone inhibition.

\begin{tabular}{|l|c|c|}
\hline \multicolumn{1}{|c|}{ SAMPLES } & E. Coli & S. aureus \\
\hline Hydroxyapatite support & $0.85[\mathrm{a}]$ & $1[\mathrm{ab}]$ \\
\hline Ag$_{3} \mathbf{P O}_{4}$ microcrystals & $1.1[\mathrm{c}]$ & $1.25[\mathrm{ab}]$ \\
\hline $\mathbf{A g}_{3} \mathbf{P O}_{4} / \mathbf{H A p - 1}$ & $1[\mathrm{c}]$ & $1.15[\mathrm{ab}]$ \\
\hline $\mathbf{A g}_{3} \mathbf{P O}_{4} / \mathbf{H A p - 2}$ & $1.1[\mathrm{~b}]$ & $1.25[\mathrm{ab}]$ \\
\hline $\mathbf{A g}_{3} \mathbf{P O}_{4} / \mathbf{H A p - 3}$ & $1.4[\mathrm{~d}]$ & $1.5[\mathrm{ab}]$ \\
\hline
\end{tabular}

The same letter means that the samples do not differ significantly at the $5 \%$ threshold.

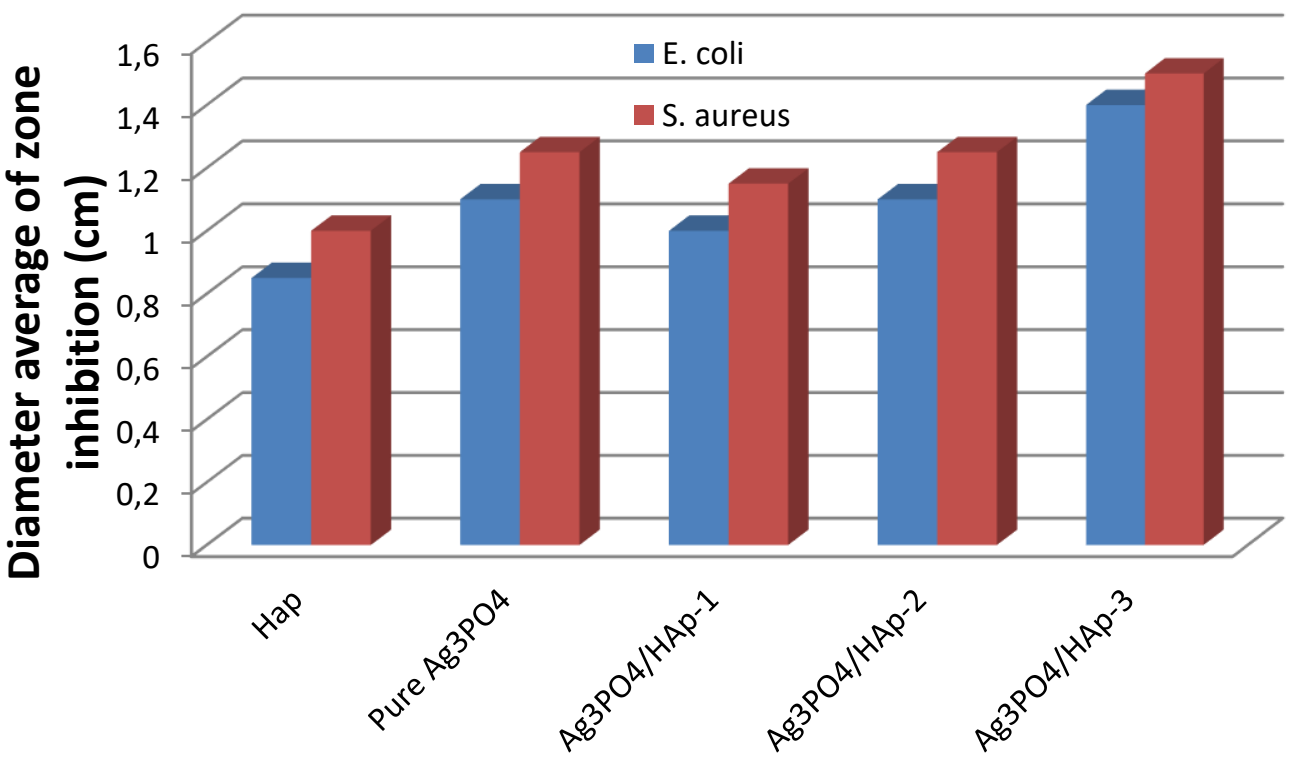

Figure 4. histograms of diameter average of zone inhibition of as-prepared samples.

A. Z. Alshemary ${ }^{25}$ et al. and N. Iqbal et al. ${ }^{26}$ reported that the HAp has no antibacterial effect against E. coli bacteria strain using the disk diffusion method while Archan et al. ${ }^{11}$ found that there is no antibacterial activity against $\mathrm{S}$. aureus using the same method. According to Tin O-o study ${ }^{12}$, the HAp microcrystals possess antibacterial activity using the broth dilution technique. In the present study, it can be seen that the HAp support acted differently and it presents a low antibacterial activity against both bacteria strain. The zones inhibition for E. coli and $\mathrm{S}$. aueus were 0.85 and $1.00 \mathrm{~cm}$ respectively. Moreover, the E. coli bacteria are less affected by antimicrobial agent $\mathrm{Ag}_{3} \mathrm{PO}_{4}$ than $\mathrm{S}$. aureus. In the literature, $\mathrm{Ag}_{3} \mathrm{PO}_{4}$ is well known for its antibacterial property. The silver ions release around the disk kill the pathogens and thus limit the growth of microorganisms.

On the other hand, the ZoI was observed for three HAp supported $\mathrm{Ag}_{3} \mathrm{PO}_{4}$ samples against E. coli and $\mathrm{S}$. aureus strains. The average inhibition zones increase when the percentage of $\mathrm{Ag}$ ions increases for two studied pathogens. The average $\mathrm{ZoI}$ of $\mathrm{Ag}_{3} \mathrm{PO}_{4} / \mathrm{HAp}$ -
1, $\mathrm{Ag}_{3} \mathrm{PO}_{4} / \mathrm{HAp}-2$ and $\mathrm{Ag}_{3} \mathrm{PO}_{4} / \mathrm{HAp}-3$ for E. coli were $1,1.1$ and $1.4 \mathrm{~cm}$ respectively. $\mathrm{Ag}_{3} \mathrm{PO}_{4} / \mathrm{HAp}-1$, $\mathrm{Ag}_{3} \mathrm{PO}_{4} / \mathrm{HAp}-2$ and $\mathrm{Ag}_{3} \mathrm{PO}_{4} / \mathrm{HAp}-3$ showed zone inhibition of $1.15,1.25$ and $1.5 \mathrm{~cm}$ toward $\mathrm{S}$. aureus. Our results are in good accordance with the authors who studied the effect of silver ions $\mathrm{Ag}^{+}$on E.coli and $\mathrm{S}$. aureus ${ }^{23},{ }^{27-31}$. The antibacterial properties of silver ions $\mathrm{Ag}^{+}$were ascribed to the high surface/volume ratio of silver particles, which gives more efficiency and enhances their antibacterial activity ${ }^{32}$.

Feng et al. and Song et al. suggested the mechanism explaining the influence of the silver ions on cell bacteria ${ }^{33,}{ }^{34}$. The $\mathrm{Ag}^{+}$ions attack the bacterium proteins at its cell wall causing cellular problems and then separate the cytoplasm from the bacterial cell wall. The silver ions may attach to bacterial DNA and RNA and thus prevents bacterial replication leading finally to the death of the cell. Mocanu et al. ${ }^{35}$ report that the silver ions attack preferably the respiratory chain and cell division. 


\section{Conclusion}

Nano-hydroxyapatite $\mathrm{HAp}$ and $\mathrm{Ag}_{3} \mathrm{PO}_{4}$ supported hydroxyapatite $\mathrm{Ag}_{3} \mathrm{PO}_{4} / \mathrm{HAp}$ were successfully synthesized. XRD data of HAp reveal the diffraction peaks typical of pure HAp apatite. The diffraction spectra of $\mathrm{Ag}_{3} \mathrm{PO}_{4} / \mathrm{HAp}$ composites show the coexistence of HAp phase and silver ions. Also, coupling $\mathrm{Ag}_{3} \mathrm{PO}_{4}$ with hydroxyapatite support reveals a high photocatalytic activity to decompose methylene blue $\mathrm{MB}$ dye comparing to pure HAp. Antibacterial tests show that the $\mathrm{Ag}_{3} \mathrm{PO}_{4} / \mathrm{HAp}$ particles have good antibacterial activity against E. coli and S. aureus strains. Consequently, our composites mainly $\mathrm{Ag}_{3} \mathrm{PO}_{4} / \mathrm{HAp}$, could be used in dental and surgical applications as a bone implant or coating metallic implants.

\section{References}

1- K. Hashimoto, H. Irie, et A. Fujishima, $\mathrm{TiO}_{2}$ Photocatalysis: A Historical Overview and Future Prospects, Jpn. J. Appl. Phys., vol 44, no 12, 2005, 8269-8285.

2- J.-M. Herrmann, Photocatalysis fundamentals revisited to avoid several misconceptions, Appl. Catal. B Environ., vol. 99, no 3-4, 2010, 461468.

3- Z. Yi, J. Ye, N. Kikugawa, T. Kako, S. Ouyang, H. Stuart-Williams, H. Yang, J. Cao, W. Luo, Z. Li, Y. Liu, R.L. Withers, Nat. Mater 9, 2010, 559-564.

4- R. Asahi, Visible-Light Photocatalysis in Nitrogen-Doped Titanium Oxides, Science, vol. 293, no 5528, 2001, 269-271.

5- Weerasak Chomkitichai, Jiraporn Pama, Pimchanok Jaiyen, Sila Pano, Jiraporn Ketwaraporn, Pusit Pookmanee, Sukon Phanichphant and Pongthep Jansanthea, Applied Mechanics and Materials, 2019, 886, 138-145.

6- N. Umezawa, O. Shuxin, et J. Ye, Theoretical study of high photocatalytic performance of $\mathrm{Ag}$ ${ }_{3}$ PO4, Phys. Rev. B, vol. 83, no 3, 2011, 035202-1-8.

7- X. Fu, W. Tang, L. Ji, et S. Chen, V2O5/A12O3 composite photocatalyst: Preparation, characterization, and the role of $\mathrm{Al} 2 \mathrm{O} 3$, Chem. Eng. J. vol. 180, 2012, 170-177.

8- W. Yao, B. Zhang, C. Huang, C. Ma, X. Song, et $\mathrm{Q}$. Xu, Synthesis and characterization of high efficiency and stable Ag3PO4/TiO2 visible light photocatalyst for the degradation of methylene blue and rhodamine B solutions, J. Mater. Chem., vol. 22, no 9, 2012, 4050.

9- H. Cui et al., Facile synthesis of graphene oxide-enwrapped Ag3PO4 composites with highly efficient visible light photocatalytic performance, Mater. Lett., vol. 93, 2013, 28-31.
10- L. Zhang, H. Zhang, H. Huang, Y. Liu, et Z. Kang, Ag3PO4/SnO2 semiconductor nanocomposites with enhanced photocatalytic activity and stability, New J. Chem., vol. 36, no 8, 2012, 1541.

11- Archan Rajendran, Rakesh C. Barik, Duraipandy Natarajan, M.S. Kiran, Deepak K. Pattanayak, Synthesis, phase stability of hydroxyapatite-silver composite with antimicrobial activity and cytocompatibility, Ceramics International 40, 2014, 10831-10838.

12- M.M. Tin-Oo, V. Gopalakrishnan, A.R. Samsuddin, K.A. Al Salihi, et O. Shamsuria, Antibacterial property of locally produced hydroxyapatite, Arch. Orofac. Sci. 2, 2007, 41-44.

13- W. Chen, Y. Liu, H.S. Courtney, M. Bettenga, C.M. Agrawal, J.D. Bumgardner, J.L. Ong, In vitro anti-bacterial and biological properties of magnetron co-sputtered silver-containing hydroxyapatite coating, Biomaterials 27, 2006, 5512-5517.

14- R.J. Chung, M.F. Hsieh, C.W. Huang, L.H. Perng, H.W. Wen, T.S. Chin, Antimicrobial effects and human gingival biocompatibility of hydroxyapatite sol-gel coatings, J. Biomed. Mater. Res. Part B 76, 2006, 169-178.

15- R.W. Sun, R. Chen, N.P. Chung, C.M. Ho, C.L. Lin, C.M. Che, Silver nanoparticles fabricated in Hepes buffer exhibit cytoprotective activities toward HIV-1 infected cells, Chem. Commun. 40, 2005, 5059-5061.

16- Wen-Ru. Li, Xiao-Bao. Xie, Qing-Shan. Shi, Hai-Yan. Zeng, You-Sheng OU-Yang, Yi-Ben. Chen, Antibacterial activity and mechanism of silver nanoparticles on Escherichia coli, Appl Microbiol Biotechnol, 2010, 1115-1122.

17- B. Chafik El Idrissi, K. Yamni, A. Yacoubi, A. Massit, A novel method to synthesize nanocrystalline hydroxyapatite: Characterization with $\mathrm{x}$-ray diffraction and infrared spectroscopy, IOSR Journal of Applied Chemistry. Volume 7, Issue 5, Ver. III, 2014, 107-112.

18- J.J. Buckley, A.F. Lee, L. Olivi, K. Wilson, Hydroxyapatite supported antibacterial Ag3PO4 nanoparticles, Journal of Materials Chemistry 20, 2010, 8056-8063.

19- Gopal Panthi, Rosa Ranjit, Hak-Yong Kim, Deependra Das Mulmi, Size-dependent optical and antibacterial properties of $\mathrm{Ag} 3 \mathrm{PO} 4$ synthesized by facile precipitation and colloidal approach in aqueous solution, Optik 156, 2018, 60-68.

20- X. Ma et al., Substantial change in the phenomenon of "self-corrosion" on Ag3PO4/TiO2 compound photocatalyst, Appl. Catal. B Environ., vol. 158-159, 2014, 314-320.

21- Y. Bi, S. Ouyang, N. Umezawa, J. Cao, et J. Ye, Facet Effect of Single-Crystalline Ag 3 PO 
4 Sub-microcrystals on Photocatalytic Properties, J. Am. Chem. Soc., vol. 133, no 17, 2011, 6490-6492.

22- Xiaoting Hong, Xiaohui Wu, Qiuyun Zhang, Mingfeng Xiao, Gelin Yang, Meirong Qiu, Guocheng Han, Hydroxyapatite supported Ag3PO4 nanoparticles with higher visible light photocatalytic activity, Applied Surface Science 258, 2012, 4801-4805.

23- V. Stanic, S. Dimitrijevic', J. Antic-Stankovic', M. Mitric', B. Jokic', Ilija B. Plecaš, S. Raicevic', Synthesis, characterization and antimicrobial activity of copper and zinc-doped hydroxyapatite nanopowders, Applied Surface Science 256, 2010, 6083-6089.

24- E. Amato, Y.A. Diaz-Fernandez, A. Taglietti, P. Pallavicini, L. Pasotti, L. Cucca, C. Milanese, P. Grisoli, C. Dacarro, J.M. Fernandez-Hechavarria, V. Necchi, Synthesis, characterization and antibacterial activity against Gram positive and Gram negative bacteria of biomimetically coated silver nanoparticles, Langmuir 27, 2011, 9165-9173.

25- Ammar Z. Alshemary, Muhammed Akram, Yi-Fan Goh, Usman Tariq, Faheem K. Butt, Ahmad Abdolahi, Rafaqat Hussain, Synthesis, characterization, in vitro bioactivity and antimicrobial activity of magnesium and nickel doped silicate hydroxyapatite, Ceramics International 41, 2015, 11886-11898.

26- Nida Iqbal, Mohammed Rafiq Abdul Kadir, Nik Ahmad Nazim Nik Malek, Nasrul Humaimi Bin Mahmood, Malliga Raman Murali, T. Kamarul, Characterization and antibacterial properties of stable silver substituted hydroxyapatite nanoparticles synthesized through surfactant assisted microwave process, Materials Research Bulletin 48, 2013, 3172-3177.

27- M. Diaz, F. Barba, M. Miranda, F. Guitian, R. Torrecillas, J.S. Moya, Synthesis, antimicrobial activity of silver-hydroxyapatite nanocomposite, J. Nanomater, 2009, Article ID 498505.
28- L.F. de Oliveira, J.O. de Gonçalves, A. Kaliandra, J. Kobarg, M.B. Cardoso, Sweeter but deadlier: decoupling size, charge and capping effects in carbohydrate coated bactericidal silver nanoparticles, J. Biomed. Nanotechnol. 9, 2013, 18171826.

29- W.R. Li, X.B. Xie, Q.S. Shi, S.S. Duan, Y.S. Ouyang, Y.B. Chen, Antibacterial effect of silver nanoparticles of Staphylococcus aureus, Biometals 24, 2011, 135-141.

30- S. Cavalu, V. Simon, G. Goller, I. Akin, Bioactivity and antimicrobial proprieties of PMMA/Ag2O acrylic bone cement collagen coated Dig. J. Nanomater. Bios. 6, 2011, 779-790.

31- M. Bellantone, H.D. Williams, L.L. Hench, Broad-spectrum bactericidal activity of $\mathrm{Ag} 2 \mathrm{O}-$ doped bioactive glass, Antimicrob. Agents Chemother. 46, 2002, 1940-1945.

32- Raffi, M., Hussain, F., Bhatti, T.M., Akhter, J.I., Hameed, A., Hasan, M.M, Antibacterial characterization of silver nanoparticles against E. coli ATCC-15224, Journal of Materials Science and TechnologyVolume 24, Issue 2, 2008, 192-196.

33- H.Y. Song, K.K. Ko, I.H. Oh, B.T. Lee, Fabrication of silver nanoparticles and their antimicrobial mechanisms, Eur. Cells. Mater. 11, 2006, 58

34- Q.L. Feng, J. Wu, G.Q. Chen, F.Z. Cui, T.N. Kim, J.O. Kim, A mechanistic study of the antibacterial effect of silver ions on Escherichia coli and Staphylococcus aureus, J. Biomed. Mater. Res. A 52, 2000, 662-668.

35- A. Mocanu, G. Furtos, S. Rapuntean, O. Horovitz, C. Flore, C. Garbo, A. Danisteanu, G. Rapuntean, C. Prejmerean, M. TomoaiaCotisel, Synthesis characterization and antimicrobial effects of composites based on multi-substituted hydroxyapatite and silver nanoparticles, Applied Surface Science 298, 2014, 225-235. 